\title{
Idiopathic non-syphilitic paroxysmal cold haemoglobinuria in children
}

\author{
G. W. G. BIRD, JUNE WINGHAM, A. J. MARTIN, S. G. N. RICHARDSON, \\ A. P. COLE, R. W. PAYNE, AND B. F. SAVAGE \\ From the West Midlands Regional Blood Transfusion Service, Birmingham, The Children's Hospital, \\ Birmingham, and the Royal Infirmary, Worcester
}

SYNOPSIS Three examples of non-syphilitic paroxysmal cold haemoglobinuria (PCH) in children are described which occurred, within a period of 16 days, in association with a febrile illness. No definite viral aetiology or obvious epidemiological association could be established. A DonathLandsteiner antibody of anti-P specificity was demonstrated in all three patients. The serological aspects of $\mathrm{PCH}$ are critically discussed.

Although paroxysmal cold haemoglobinuria (PCH) is relatively uncommon, it was the first autoimmune haemolytic anaemia to be described (Donath and Landsteiner, 1904). Indeed, the discovery of this disorder constituted the foundation of immunohaematology, and the laboratory test for its diagnosis, the Donath-Landsteiner (DL) reaction, was the first immunohaematological test ever to be described.

In the earlier period of its history, $\mathrm{PCH}$ usually occurred as a chronic complication of syphilis. Syphilis is, however, not as common as it used to be so that, in recent years, PCH occurs more often as a transient sequel to certain virus infections, eg, chicken pox (Kaiser and Bradford, 1929), measles (Dacie, 1954; O'Neill and Marshall, 1967), mumps (Colley, 1964), and an 'influenza-like' illness (Nelson and Nicholl, 1960). An example of PCH has been reported which followed prophylactic immunization against measles (Bunch et al, 1972). Some examples of $\mathrm{PCH}$ are classified as idiopathic and may be transient or chronic (Dacie, 1962). They are usually associated with fever of obscure origin.

The serology of PCH is still essentially the same as that described by Donath and Landsteiner (1904) except for two additional features which were demonstrated later. The direct antiglobulin (Coombs) test is positive, and the antibody almost invariably has the specificity anti-P (Worlledge and Rousso, 1965; Mollison, 1972) within the P blood group system (table 1). Other specificities have been described; they are discussed below. The antibody is of the IgG class and is biphasic, correctly bithermic,

Received for publication 15 September 1975

\begin{tabular}{|c|c|c|c|}
\hline \multirow{2}{*}{$\begin{array}{l}\text { Red Cells } \\
\text { (phenotype) }\end{array}$} & \multicolumn{3}{|l|}{ Antibody } \\
\hline & $\begin{array}{l}\text { Anti-P } P_{1} \\
\text { (formerly } \\
\text { anti-P) }\end{array}$ & $\begin{array}{l}\text { Anti-P }+P^{k} \\
(\text { formerly } \\
\left.\text { anti- } T j^{\mathrm{a}}\right)\end{array}$ & $\begin{array}{l}\text { Anti-P } \\
\text { (DL antibody) }\end{array}$ \\
\hline $\begin{array}{l}\mathbf{P}_{1} \\
\mathbf{P}_{2} \\
\mathbf{P}_{1} \\
\mathbf{P}_{1} \\
\mathbf{p}_{2}\end{array}$ & $\begin{array}{l}+ \\
- \\
+ \\
-\end{array}$ & $\begin{array}{l}+ \\
+ \\
+ \\
+ \\
+\end{array}$ & $\begin{array}{l}+ \\
+ \\
- \\
-\end{array}$ \\
\hline
\end{tabular}

Table I Serology of the DL and related antibodies within the P blood group system

in the sense that sensitization and complementfixation takes place at low temperatures (comparatively high in non-syphilitic examples, see below) and lysis occurs at or near body temperature. The antibody is essentially haemolytic. In our experience, it is also haemagglutinating, but only in the sense that it gives positive antiglobulin tests; this is discussed below. Its specificity can therefore be demonstrated either by haemolysis or by indirect antiglobulin tests.

There are serological differences in the syphilitic and non-syphilitic types of PCH. The thermal amplitude of erythrocyte sensitization in the nonsyphilitic type is much greater than in the syphilitic type (Schubothe and Haenle, 1961). Antibody binding in the non-syphilitic type may occur at temperatures as high as $32^{\circ} \mathrm{C}$ (Ries et al, 1971), whereas it usually occurs below $20^{\circ} \mathrm{C}$ in the syphilitic type. Furthermore, the antibody is usually persistent in the syphilitic type of $\mathrm{PCH}$, whereas it is often transient in non-syphilitic PCH. 


\section{Case Reports}

In our region, the incidence of $\mathrm{PCH}$ has previously never been more than one case in 12 months. We here report three patients studied between 2 and 17 February 1975.

\section{CASE 1}

JB, a 9-year-old boy, was admitted on 11 February 1975 complaining of back pain and the passage of dark red urine. There was no significant past history. On 3 February he had developed an 'influenzal' illness for which he received a course of co-trimoxazole. On 10 February there was increasing malaise, anorexia, right loin pain, and dark red urine. He was pale and slightly icteric; there was nothing else abnormal.

\section{Investigations}

On admission: $\mathrm{Hb} 10 \cdot 1 \mathrm{~g} / \mathrm{dl}$; Het $0 \cdot 2$; MCHC 34.0 $\mathrm{g} / \mathrm{dl}$; WBC $6.7 \times 10^{9} / \mathrm{l}$; differential count normal; reticulocytes $1.0 \%$; blood film-occasional fragmented red cells and spherocytes; urine-dark red, no red cells present, methaemoglobin present; blood urea $9.6 \mathrm{mmol} / \mathrm{l}$; serum bilirubin $32 \mu \mathrm{mol} / \mathrm{l}$; liver function tests normal.

Further investigations: Unstable haemoglobins negative; G6PD deficiency (Sigma) negative; direct Coombs test positive; Donath-Landsteiner antibody positive; urine porphyrins not detected; WR and VDRL negative.

Progress: No treatment was given. He was discharged on 17 February 1975 and seen regularly as an outpatient.

Subsequent investigations: These are tabulated below:

\begin{tabular}{|c|c|c|c|c|}
\hline Date & $H b(g / d l)$ & $\begin{array}{l}\text { Reticulo- } \\
\text { cytes }(\%)\end{array}$ & $\begin{array}{l}\text { Direct } \\
\text { Coombs } \\
\text { Test }\end{array}$ & $\begin{array}{l}D L \\
\text { Antibody }\end{array}$ \\
\hline $\begin{array}{r}11 \text { Feb } \\
13 \text { Feb } \\
17 \text { Feb } \\
20 \text { Feb } \\
4 \mathrm{Mar} \\
12 \mathrm{Mar} \\
9 \mathrm{Apr} \\
7 \mathrm{May}\end{array}$ & $\begin{array}{r}10 \cdot 1 \\
8 \cdot 7 \\
9 \cdot 3 \\
12 \cdot 1 \\
12 \cdot 4 \\
13 \cdot 1 \\
13 \cdot 9 \\
13 \cdot 3\end{array}$ & $\begin{array}{r}1 \cdot 2 \\
2 \cdot 2 \\
2 \cdot 2 \\
2 \cdot 4 \\
11 \cdot 2 \\
12 \cdot 0 \\
1 \cdot 0\end{array}$ & $\begin{array}{l}\text { Positive } \\
\text { Positive } \\
\text { Positive } \\
\text { Negative } \\
\text { Negative } \\
\text { Negative }\end{array}$ & $\begin{array}{l}\text { Positive } \\
\text { Positive } \\
\text { Positive } \\
\text { Positive }\end{array}$ \\
\hline
\end{tabular}

Viral studies: complement fixation test to influenza $\mathrm{A}$

12 Feb 1:32 12 Mar $1: 32$

\section{CASE 2}

CI, a 3-year-old boy, was admitted on 17 February 1975 complaining of vomiting, abdominal pain, and the passage of red urine. There was no significant past history. On 14 February he had developed abdominal pain and vomiting; he passed dark red urine the next day. On 17 February there was fever and jaundice. He was treated with ampicillin and cloxacillin.

\section{Investigations}

On admission: $\mathrm{Hb} 5.5 \mathrm{~g} / \mathrm{dl}$; Hct 0.185 ; MCHC 36.0 $\mathrm{g} / \mathrm{dl}$; WBC $8.2 \times 10^{9} / 1$; neutrophil leucocytosis; reticulocytes $22 \%$; blood film-occasional fragmented cells and marked polychromasia; urinedark red, no red cells present, methaemoglobin present; blood urea $2.0 \mathrm{mmol} / \mathrm{l}$; serum bilirubin $82 \mu \mathrm{mol} / \mathrm{l}$.

Further investigations: Unstable haemoglobins negative; G6PD deficiency (Sigma) negative; Schumm's test-methaemalbumin present in serum; direct Coombs test positive; Donath-Landsteiner antibody present; urine porphyrins not detected; WR and VDRL negative.

Progress: Pulse rate continued to rise after admission. He was transfused one unit of warmed packed red cells. Subsequent progress was uneventful and he was discharged on 3 March 1975 and seen regularly as an outpatient.

Subsequent investigations: These are tabulated below:

\begin{tabular}{|c|c|c|c|c|}
\hline Date & $H b(g / d l)$ & $\begin{array}{l}\text { Reticulo- } \\
\text { cytes }(\%)\end{array}$ & $\begin{array}{l}\text { Direct } \\
\text { Coombs } \\
\text { Test }\end{array}$ & $\begin{array}{l}D L \\
\text { Antibody }\end{array}$ \\
\hline $\begin{array}{l}22 \text { Feb } \\
23 \text { Feb }\end{array}$ & $\begin{array}{l}5 \cdot 5 \\
7 \cdot 7 \text { (post- } \\
\text { transfusion) }\end{array}$ & $\begin{array}{r}22 \cdot 0 \\
6 \cdot 8\end{array}$ & Positive & Positive \\
\hline $\begin{aligned} & 26 \text { Feb } \\
& 3 \mathrm{Mar}\end{aligned}$ & $\begin{array}{l}7 \cdot 8 \\
9 \cdot 5\end{array}$ & $22 \cdot 0$ & & \\
\hline $\begin{array}{l}12 \mathrm{Mar} \\
9 \mathrm{Apr} \\
7 \mathrm{May}\end{array}$ & $\begin{array}{l}11 \cdot 2 \\
12 \cdot 2 \\
11 \cdot 9\end{array}$ & $\begin{array}{l}0.6 \\
1.5\end{array}$ & $\begin{array}{l}\text { Negative } \\
\text { Negative } \\
\text { Negative }\end{array}$ & $\begin{array}{l}\text { Positive } \\
\text { Negative } \\
\text { Negative }\end{array}$ \\
\hline
\end{tabular}

Viral studies: Complement fixation to adenovirus group $\begin{array}{llll}28 \mathrm{Feb} & 1: 8 \quad 22 \mathrm{Apr} & 1: 64\end{array}$

CASE 3

KB, a 5-year-old girl, was admitted on 5 February 1975 complaining of fever, cough, and the passage of red urine. She had received one week's treatment with penicillin. Her condition improved but she or passed red urine on the day of admission.

\section{Investigations}

On admission: A pale child with a slight tinge of icterus. In the respiratory system there were some scattered crepitations over the right base only; upper respiratory passages were clear. Abdomen normal; $\mathrm{Hb} 9.4 \mathrm{~g} / \mathrm{dl}$; reticulocytes $4.8 \%$; WBC 9.0 $\times 10^{9} / 1$; ESR $110 \mathrm{~mm}$ in 1 hour; serum bilirubin $54.7 \mu \mathrm{mol} / 1$.

Further investigations: Urine-no cells, methaemoglobin present; direct Coombs test positive; 
haptoglobin $250 \mathrm{mg} / \mathrm{l}$; Donath-Landsteiner test positive; ASOT normal, less than 200 units per $\mathrm{ml}$; immunoglobulins: IgG $9.6 \mathrm{~g} / \mathrm{l}$ (normal), IgA $3.9 \mathrm{~g} / \mathrm{l}$ (normal), IgM $2.3 \mathrm{~g} / 1$ (raised); chest $x$-ray shows consolidation of the right lower lobe, later resolving but not clearing; mycoplasma antibodies not detected.

Subsequent progress: She was discharged on 18 February and was later seen in outpatients. Her progress was uneventful.

In all three cases, the upper limit of sensitization temperature was about $25^{\circ}$. No drug-induced or Mycoplasma pneumoniae antibodies were detected. All three antibodies were of the IgG class. We do not know why the IgM level in case 3 was significantly raised. The important features of the cases are summarized in table II.

\section{Discussion}

The viral antibody titres observed in our patients are not of diagnostic significance. It may be assumed, however, that an unknown organism, probably a virus, was responsible. From our observations on our patients and those of others (eg, Vogel et al, 1972) it is clear that $\mathrm{PCH}$ may occur, particularly in children, as a complication of febrile illness of obscure origin. The occurrence of our three cases within a 16-day period does, of course, suggest an epidemiological association. However, no supportive evidence was obtained either from laboratory investigations or from Public Health Reports. The clustering may have occurred by chance.

The DL antibody in each of our patients was typically anti-P; it was transient in two (CI and KB) and persistent in one (JB). A few examples of $\mathrm{PCH}$ have, however, been described in which the DL antibody apparently had specificities other than anti-P, eg, those of Weiner et al (1964), Bell et al (1973), and Wishart and Davey (1973). The antibody of Bell et al (1973) was anti-I, and in the other two examples specificity was not established. We wonder if these were true DL antibodies. It is possible that, in some cases, cold autoagglutinins such as anti-I or anti-i may have been present in addition to a DL antibody, for example, the cases of Stewart and Friedlander (1957), Bell et al (1973), Wishart and Davey (1973), and Djaldetti et al (1975).

The cases of Stewart and Friedlander (1957) and Bell et al (1973) were associated with primary atypical pneumonia (Mycoplasma pneumoniae infection) in which anti-I is usually present, and the case of Wishart and Davey (1973) was associated with infectious mononucleosis in which anti-i is often present. The antibodies in all three of these cases were strongly haemagglutinating. A similar example was reported by Neely et al (1951), who believed, probably correctly, that the DL test was falsely positive. In the case of Malley and Hickey (1949), described as PCH of the non-syphilitic type, the DL test was negative. This was probably an example of transient cold agglutinin disease. The term PCH has been used to include cold agglutinin disease, for example, by van Loghem et al (1963). This practice may confuse clinicians and should be avoided; we suggest the term PCH should be confined to the condition caused by DL antibody. Although the DL antibody is held to be both haemolytic and haemagglutinating (Dacie, 1962), we doubt if DL antibodies are ever haemagglutinating, except in the sense mentioned in the introduction to the present paper.

The antibody described by Weiner et al (1964) was later said to be anti-HI (Mollison, 1972). Inspection of Weiner's protocols, however, showed that the antibody reacted much more strongly on group $\mathbf{O}$,

\begin{tabular}{|c|c|c|c|}
\hline & $\begin{array}{l}\text { Case I } \\
\text { JB }\end{array}$ & $\begin{array}{l}\text { Case } 2 \\
\text { CI }\end{array}$ & $\begin{array}{l}\text { Case } 3 \\
\boldsymbol{K B}\end{array}$ \\
\hline $\begin{array}{l}\text { Age (yr) } \\
\text { Date of admission } \\
\text { Presenting signs }\end{array}$ & $\begin{array}{l}9 \\
11 \text { February } 1975 \\
\text { Back pain, right loin pain, } \\
\text { dark red urine (fever before } \\
\text { admission) }\end{array}$ & $\begin{array}{l}3 \\
22 \text { February } 1975 \\
\text { Fever, vomiting, } \\
\text { abdominal pain, dark urine }\end{array}$ & $\begin{array}{l}5 \\
5 \text { February } 1975 \\
\text { Fever (later-red urine) }\end{array}$ \\
\hline $\begin{array}{l}\text { Tests for syphilis } \\
\text { Virology } \\
\text { Viral complement-fixation titre } \\
\text { Tests for Mvcoplasma pneumoniae } \\
\text { Tests for relevant drug-induced antibody } \\
\text { DL antibody } \\
\text { Specificity of antibody } \\
\text { Direct Coombs test } \\
\text { Cold haemagglutinins } \\
\text { Persistence of antibody } \\
\text { Upper limit of sensitization temperature }\end{array}$ & $\begin{array}{l}\text { Negative } \\
\text { Influenza A } \\
32 \\
\text { Negative } \\
\text { Negative } \\
\text { Positive } \\
\text { Anti-P } \\
\text { Positive } \\
\text { Negative } \\
\text { Persistent } \\
25^{\circ}\end{array}$ & $\begin{array}{l}\text { Negative } \\
\text { Adenovirus } \\
64 \\
\text { Negative } \\
\text { Negative } \\
\text { Positive } \\
\text { Anti-P } \\
\text { Positive } \\
\text { Negative } \\
\text { Transient } \\
25^{\circ}\end{array}$ & $\begin{array}{l}\text { Negative } \\
\text { Echo } 19^{1} \\
\text { Negative } \\
\text { Negative } \\
\text { Negative } \\
\text { Positive } \\
\text { Anti-P } \\
\text { Positive } \\
\text { Negative } \\
\text { Transient } \\
25^{\circ}\end{array}$ \\
\hline
\end{tabular}

Table II Comparison of the main features of three examples of idiopathic PCH

1Virus isolated from throat; regarded as probable contaminant. 
$p p$ cells than on P-positive cells so that its relatively strong action on $p p$ cells cannot be ascribed to an anti-HI effect. We tested the red cells of Weiner's $p p$ donor and found $\mathrm{H}, \mathrm{I}$, and $\mathrm{i}$ antigen strengths to be normal. The ABO, $\mathrm{H}, \mathrm{I}, \mathrm{i}$, and $\mathrm{P}$ systems are known to be interrelated (Allen et al, 1974; Bird, 1975), so that the specificity of some DL antibodies may well 'cut across' these systems. The DL antibody described by Engelfriet $e$ t al (1971) was possibly anti-p and, in retrospect, the antibody of Weiner $e t$ al (1964) was possibly an antibody with similar specificity.

We suggest that, in future investigations of $\mathrm{PCH}$, DL antibodies with atypical specificity should be carefully investigated for possible interrelationship with the $P$ system. We are also inclined provisionally to confine the definition of the classical or DL type of PCH as a haemolytic anaemia caused by a bithermic complement-fixing IgG autoantibody (autohaemolysin) which has specificity, usually anti-P, within the P blood group system.

\section{References}

Allen, F. H., Jr., Marsh, W. L., Jensen, L., and Fink, J. (1974). Anti-IP: an antibody defining another product of interaction between the genes of the $I$ and $P$ blood group systems. Vox Sang. (Basel), 27, 442-446.

Bell, C. A., Zwicker, H., and Rosenbaum, D. L. (1973). Paroxysmal cold haemoglobinuria (P.C.H.) following mycoplasma infection : anti-I specificity of the bithermic hemolysin. Transfusion (Philad.), 13, 138-141.

Bird, G. W. G. (1975). Cell membrane receptors for serological reagents. $J$. med. Genet., 12, 174-184.

Bunch, C., Schwartz, F. C. M., and Bird, G. W. G. (1972). Paroxysmal cold haemoglobinuria following measles immunization. Arch. Dis. Childh., 47, 299-300.

Colley, E. W. (1964). Paroxysmal cold haemoglobinuria after mumps. Brit. med. J., 1, 1552-1523.

Dacie, J. V. (1954). The Haemolytic Anaemias, Congenital and Acquired, p. 228. Churchill, London.

Dacie, J. V. (1962). The Haemolytic Anaemias, Part II: The Auto-immune Haemolytic Anaemias, 2nd edition, p. 560. Churchill, London.

Djaldetti, M., Elion, D., Bessler, H., and Fishman, P. (1975). Paroxysmal cold hemoglohinuria: transmission and scann- ing electron microscopy features of erythrocytes. Amer. $J$. clin. Path., 63, 804-810.

Donath, J. and Landsteiner, K. (1904). Ueber paroxysmale Hämoglobinurie. Münch med. Wschr., 51, 1590-1593.

Engelfriet, C. P., Beckers, D., von dem Borne, A. E. G. Kr., Reynierse, E., and van Loghem, J. J. (1971). Haemolysins probably recognising the antigen p. Vox Sang. (Basel), 23, 176-181.

Kaiser, A. D. and Bradford, W. L. (1929). Severe haemoglobinuria in a child, occurring in the prodromal stage of chicken pox. Arch. Pediat., 46, 571-577.

van Loghem, J. J., Peetoom, F., van der Hart, M., van der $\overrightarrow{0}$ Veer, M., van der Giessen, M., Prins, H. K., Zurcher, C., and Engelfriet, C. P. (1963). Serological and immuno- $\vec{\omega}$ chemical studies in haemolytic anaemia with high-titre cold agglutinins. Vox Sang. (Basel), 8, 33-46.

Malley, L. K. and Hickey, M. D. (1949). Paroxysmal cold haemoglobinuria of the non-syphilitic type. Lancet, 1, 387-390.

Mollison, P. L. (1972). Blood Transfusion in Clinical Medi- i cine, 5th edition, pp. 369-371. Blackwell, Oxford.

Neely, F. L., Baria, W. H., Smith, C., and Stone, C. F., Jr., (1951). Primary atypical pneumonia with high-titre of cold haemagglutinins, hemolytic anemia, and false positive Donath-Landsteiner test. J. Lab. clin. Med., 37, 382-387.

Nelson, M. G. and Nicholl, B. (1960). Paroxysmal cold haemoglobinuria. Irish J. med. Sci., 49-57.

O'Neill, B. J. and Marshall, W. C. (1967). Paroxysmal cold haemoglobinuria and measles. Arch. Dis. Childh., 42, 183186.

Ries, C. A., Garratty, G., Petz, L. D., and Fudenberg, H. H. (1971). Paroxysmal cold hemoglobinuria: report of a case with an exceptionally high thermal range DonathLandsteiner antibody. Blood, 38, 491-499.

Schubothe, H. and Haenle, M. (1961). Serologische Studien über die nichtsyphilitische Variante des Donath-Landsteinerschen Hämolysins. Vox Sang. (Basel), 6, 455-468.

Stewart, J. W. and Friedlander, P. H. (1957). Haemoglobinuria and acute haemolytic anaemia associated with primary atypical pneumonia. Lancet, 2, 774-775.

Vogel, J. M., Hellman, M., and Moloschok, R. E. (1972). Paroxysmal cold hemoglobinuria of nonsyphilitic etiology in two children. J. Pediat., 81, 974-977.

Weiner, W., Gordon, E. G., and Rowe, D. (1964). A DonathLandsteiner antibody (non-syphilitic type). Vox Sang. (Basel), 9, 684-697.

Wishart, M. M. and Davey, M. G. (1973). Infectious mononucleosis complicated by acute haemolytic anaemia with a positive Donath-Landsteiner reaction. J. clin. Path., 26, 332-334.

Worlledge, S. M. and Rousso, C. (1965). Studies on the serology of paroxysmal cold haemoglobinuria (P.C.H.) with special reference to its relationship with the $\mathbf{P}$ blood group system. Vox Sang. (Basel), 10, 293-298. 